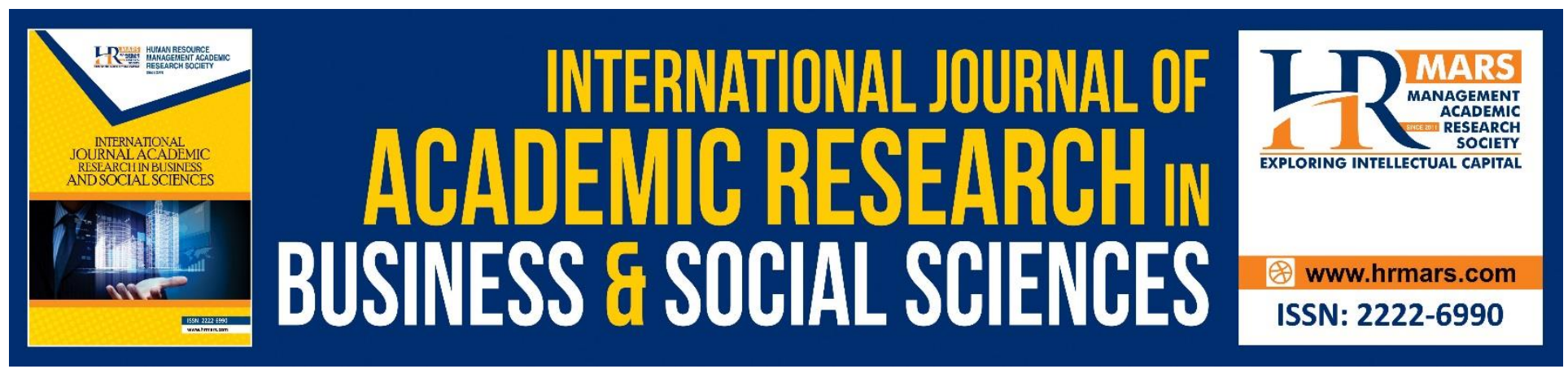

\title{
The Effect of Board Size and Independent Director Composition on Firm's Capital Structure: A Study on Malaysian Plantation Companies
}

Adelina Ebun and Suzieyana Abdullah

To Link this Article: http://dx.doi.org/10.6007/IJARBSS/v10-i8/7623

DOI:10.6007/IJARBSS/v10-i8/7623

Received: 18 May 2020, Revised: 20 June 2020, Accepted: 21 July 2020

Published Online: 30 August 2020

In-Text Citation: (Ebun, Abdullah, 2020)

To Cite this Article: Ebun, A., and Abdullah, S. (2020).The Effect of Board Size and Independent Director Composition on Firm's Capital Structure: A Study on Malaysian Plantation Companies. International Journal Academic Research in Business and Social Sciences. 10(8), 752-762.

Copyright: (C) 2020 The Author(s)

Published by Human Resource Management Academic Research Society (www.hrmars.com)

This article is published under the Creative Commons Attribution (CC BY 4.0) license. Anyone may reproduce, distribute, translate and create derivative works of this article (for both commercial and non-commercial purposes), subject to full attribution to the original publication and authors. The full terms of this license may be seen

at: http://creativecommons.org/licences/by/4.0/legalcode

Vol. 10, No. 8, 2020, Pg. 752 - 762

Full Terms \& Conditions of access and use can be found at http://hrmars.com/index.php/pages/detail/publication-ethics 


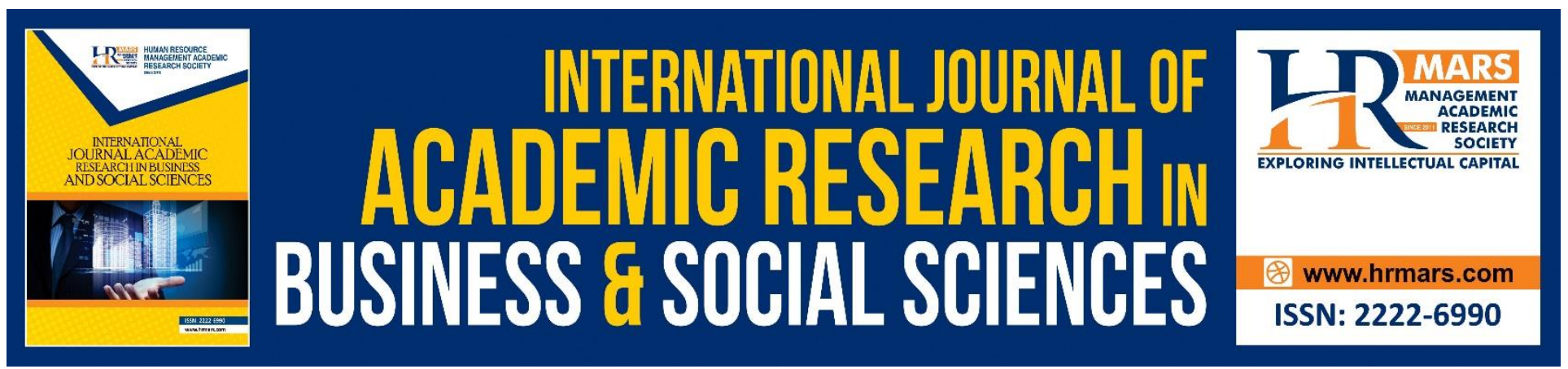

\title{
The Effect of Board Size and Independent Director Composition on Firm's Capital Structure: A Study on Malaysian Plantation Companies
}

\author{
Adelina Ebun and Suzieyana Abdullah \\ Universiti Teknologi MARA Sabah, Locked Bag 71, 88997 Kota Kinabalu, Sabah. \\ Email: adelinae@uitm.edu.my, suzieyanaabdullahh@gmail.com
}

\begin{abstract}
Board of Director (BOD) is an important corporate governance mechanism that is useful in monitoring and controlling the opportunistic behavior of corporate managers. Hence, the size of BOD is expected to have an impact on corporate managers' decisions with respect to a firm's capital structure. Using a total of 44 Malaysian plantation companies as sample, this study investigates whether BOD size and independent director's composition in the board impacted firms' capital structure. Findings of this study showed that both the size of BOD and the presence of independent directors in the board have an impact on firm's debt components but not the equity.
\end{abstract}

Keywords: Board Size, Capital Structure, Corporate Governance, Malaysian Plantation Companies.

\section{Introduction}

One of the key aspects in business is the management of its capital structure. Capital structure refers to the combination of debt and equity that are used by firm to finance its assets (Shapiro and Balbirer, 2000). Ideally, the capital structure components have to be maintained at an optimal level that would lower the cost of capital for the purpose of maximizing the shareholders' wealth. While the capital is structured to ensure a firm's operation is well functioning, the types and sources as well as the amount of a firm's capital structure depend largely on the decisions of its corporate managers. Oftentimes the capital components are decided not in the best interest of the shareholders but rather to benefits corporate managers (Ranti, 2013). To address the abovementioned issue, the corporate governance system is expected to provide a protection to shareholders and help in minimizing conflicts that may arise between shareholders and corporate managers with respect to the capital structure decision. Ranti (2013) suggested that organizations with a better governance system are more likely to have lesser agency conflicts and this consequently contributes towards the enhancement of the firms' value. Weisbach (2003) as cited by Kim et al. (2012) argued that corporate governance, particularly the size of BOD and the involvement of independent board members, are two important factors that could influence the decision of an organization's capital structure. The 
INTERNATIONAL JOURNAL OF ACADEMIC RESEARCH IN BUSINESS AND SOCIAL SCIENCES Vol. 10, No. 8, 2020, E-ISSN: 2222-6990 @ 2020 HRMARS

study highlighted the importance of BOD as key assets of an organization whose expertise, in term of knowledge and skills, are expected to contribute towards the overall development and performance of an organization. In addition, this human capital is important since their involvement in the board is vital to ensure corporate management decisions are made in the best interest of the organization as a whole. However, a review of past studies showed that studies examining the effect of BOD size on firm's capital structure are still very few particularly from the context of developing countries (examples of studies conducted in developing countries are Kumar and Singh, 2013; Tarus, 2016). Additionally, most studies that have examined the relationship had focused on companies in general. There appear to be limited studies that use companies in specific industry to test the hypothesis. Hence, this study aims to address these research gaps by investigating whether BOD size and independent director composition in the board impacted the capital structure of 44 plantation companies listed on the main board of the Kuala Lumpur Stock Exchange (KLSE). In doing so, the study attempts to determine:

- whether consistent with previous studies, board size and the independent director composition in the board is an effective corporate govenance mechanism that can be used to monitor and control the opportunistic behaviour of corporate managers in relation to the capital structure decision.

In the ensuing section, a review of relevant literature is provided. This is followed by an explanation of the research methodology and research findings. The conclusion is provided in the final section of the paper.

\section{Literature Review}

A number of past studies have shown that board size plays an important role in determining the effectiveness of a company's corporate governance system. For example, Raheja (2005) suggested that a few members in the BOD is better because smaller BOD size has a relatively lower coordination cost. He also argued that a large number of members in the BOD present a challenge for a company in terms of their collective effectiveness as well as individual participation. On contrary, some studies have found that larger board size provide a greater monitoring mechanism and serves as an effective advisory unit (Ji, 2016). In addition, improved transparency can be achieved by the presence of more directors who have relevant knowledge and therefore could provide meaningful advice on specific area of concern (Anderson et al., 2004).

There are several factors that were found to affect BOD size. Fama and Jensen (1983) cited in Germain (2014) suggested that BOD size is influenced by firm's size. They argued that larger firms have complex hierarchy in term of its organizational chart and therefore will require a larger BOD size. Their argument lies on the notion that larger firms have complex operational system and thus needed a larger BOD for counsel and information. In addition, Ting (2011) found that a firm's profitability is negatively related to BOD size. The study also found that BOD size is not only affected by firm's profitability but also the firm's age and firm's size. Hasan and Butt (2009) found that there is a significant negative correlation between BOD size and firms' leverage where larger board size tends to opt for equity in comparison to debts in order to improve the firm's performance. The finding was supported by Berger (1997); Abor (2007) who found that board size is related to the level of the firms' leverage. The study suggested that larger BOD size tends to have lower leverage levels in order to 
avoid risk that may be resulted from debt defaults. In addition, Tarus (2016) found a positive relationship between idependent directors on the board and the level of firm's debt. The study concluded that the presence of independent directors in the board is an effective mechanism to control the tendencies of corporate managers to act in an oppotunistic manner. Other studies such as Heng et al. (2012); Alves (2015); Ji (2016) found a positive association between board size and capital structure in general.

However, while the research findings discussed above have shown a negative relationship between BOD size and firm profitability, other studies have shown contradictory results. Unlike the finding of Ting (2011), Dagsson (2011) found that board size is positively related to firm's profitability. The study also found that larger firms with a high return (based on ROA) tend to have larger BOD size. A similar result was also retained in Black and Kim (2012), where BOD size was found to be positively associated with firm's size and profitability. The positive association between BOD size and firm's profitability was also evident in a number of studies such as Rosenstein and Wyatt (1990) as cited in Jermias (2014), Daily and Dalton (1993) and Hanoku Bathula (2008).

\section{Theoretical Perspective}

This study uses the agency theory to provide explanation about the relationship between board size and capital structure. The agency theory describes the relationship between the principal and the agent, by which certain decision-making powers were delegated to the agent by the principal to perform a duty on behalf of the principal (Jensen, 1986 cited in Boučková (2015). However, the agency theory recognizes the imperfection of the relationship where the agent (corporate managers) may not always act in the best interest of the principal (shareholders) (Nkundabanyanga et al., 2013). Shareholders are interested in maximizing the value of the firms while managers are more concerned with their own short term personal gains. Previous studies have extensively discussed how corporate managers used compensation based incentive scheme to achive this purpose (Schipper, 1989). To mitigate the agency conflicts arising from this situation, the corporate governance system is key in ensuring that the shareholders' interests are protected. As such, the role of BOD as part of the corporate governance elements is arguably a useful mechanism that can be used to monitor and control the opportunistic behavior of a firm's managers. Based on this argument, the BOD size and the presence of independent members in the board is expected to provide an efficient monitoring mechanism to reduce the agency costs which emerged from the divergence of interests between shareholders and managers.

\section{Research Methodology}

The main objective of this study is to examine the correlation between board size and the capital structure component of 44 Malaysian plantation companies listed on the main board of KLSE. For the purpose of achieving the research objective, data was collected from two main sources; DataStream and the companies' annual reports. The data was then analyzed using the Statistical Package for Social Science (SPSS) software.

\section{Descriptive Statistics}

Table 4.1 provides an overview of the data considered in this study. On average, total equity of the 44 Malaysian plantation companies over the 5-year period of observations was RM30,051,192. The 
INTERNATIONAL JOURNAL OF ACADEMIC RESEARCH IN BUSINESS AND SOCIAL SCIENCES Vol. 10, No. 8, 2020, E-ISSN: 2222-6990 @ 2020 HRMARS

average value of total debt and total assets are RM9,602,038 and RM17,564,613 respectively. Based on the median, about fifty per cent of the companies owned total equity of RM4,182,527, total debts RM1,560,753 and total assets RM6,008,868.

Table 4.1: Descriptive Statistics of Capital Structure Components

\begin{tabular}{|c|c|c|c|c|c|c|c|}
\hline & & $\mathrm{n}$ & Minimum & Maximum & Mean & Median & $\begin{array}{l}\text { Std. } \\
\text { Deviation }\end{array}$ \\
\hline $\begin{array}{l}\text { Total } \\
\text { (RM) }\end{array}$ & Equity & 44 & 402,793 & $\begin{array}{l}953,665,57 \\
8\end{array}$ & $\begin{array}{l}30,051,19 \\
2\end{array}$ & $4,182,527$ & $\begin{array}{l}142,962,60 \\
9\end{array}$ \\
\hline $\begin{array}{l}\text { Total } \\
\text { (RM) }\end{array}$ & Debts & 44 & 15,562 & $\begin{array}{l}100,144,22 \\
8\end{array}$ & $9,602,038$ & $1,560,753$ & $21,053,774$ \\
\hline $\begin{array}{l}\text { Total } \\
\text { (RM) }\end{array}$ & Assets & 44 & 825,654 & $\begin{array}{l}122,267,18 \\
6\end{array}$ & $\begin{array}{l}17,564,61 \\
3\end{array}$ & $6,008,868$ & $29,638,758$ \\
\hline
\end{tabular}

The 5-year trend of the companies' capital structure as depicted in Figure 4.1 shows that total equity was more than total debt. This shows that that the firms' total assets were largely financed using companies' equity. 
INTERNATIONAL JOURNAL OF ACADEMIC RESEARCH IN BUSINESS AND SOCIAL SCIENCES Vol. 10, No. 8, 2020, E-ISSN: 2222-6990 @ 2020 HRMARS

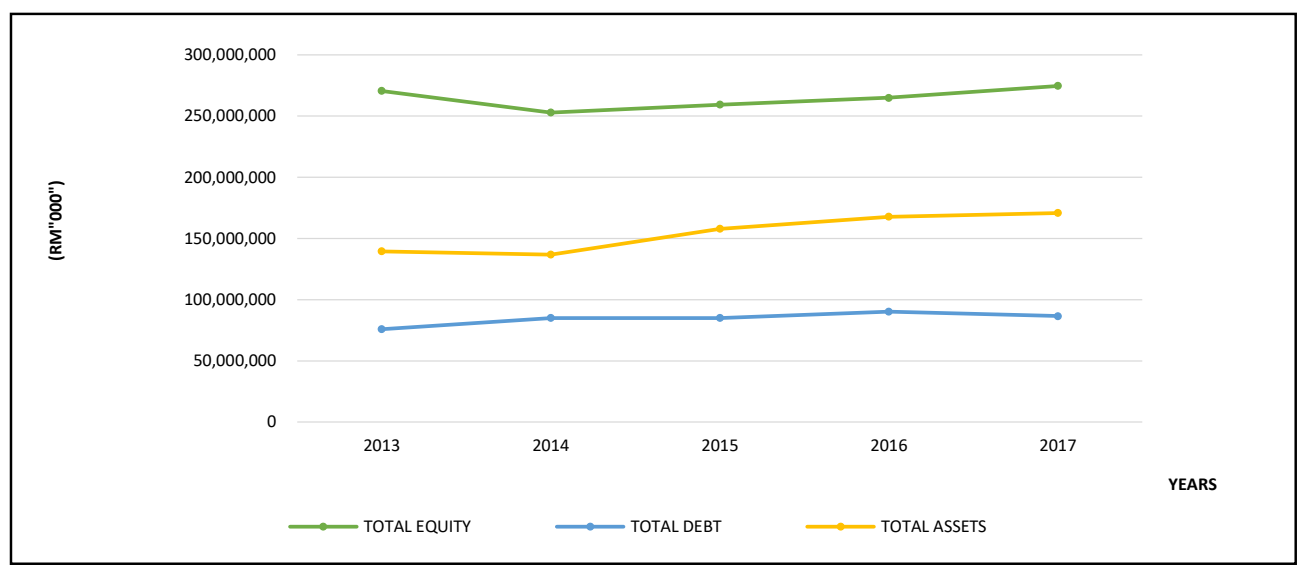

Figure 4.1: A 5-year trend of Companies Capital Structure

Table 4.2 provides a summary of the return on equity and debt ratio for the 44 Malaysian plantation companies over the 5 -year period of observation. As shown in the table, the average return on equity was $7 \%$ whereas the average debt was $36.21 \%$. About fifty per cent of the companies have a return on equity of $5.47 \%$ and debt ratio of $3.88 \%$.

Table 4.2: Descriptive Statistics of Return on Equity and Debt Ratio

\begin{tabular}{|c|c|c|c|c|c|c|}
\hline & $\mathrm{n}$ & Minimum & Maximum & Mean & Median & $\begin{array}{l}\text { Std. } \\
\text { Deviation }\end{array}$ \\
\hline $\begin{array}{l}\text { Return } \\
\text { Equity }\end{array}$ & on 44 & 0.01 & 0.19 & 0.0701 & 0.0547 & 0.05054 \\
\hline Debt Ratio & 44 & 0.01 & 0.82 & 0.3621 & 0.3889 & 0.021320 \\
\hline
\end{tabular}

As for the board membership, Table 4.3 shows that the companies has on average 39 members and 17 independent directors serving in the board. Apart from that, fifty per cent of the companies have total board member of 35 members and 17 independent directors respectively.

Table 4.3: Descriptive Statistics of Board Membership

\begin{tabular}{lllllll}
\hline \multicolumn{1}{c}{ Total } & $\mathrm{n}$ & $\mathrm{m}$ & Minimu & & & \\
\hline Board Size & 44 & 20 & 85 & 39 & 35 & 13 \\
$\begin{array}{l}\text { Independent } \\
\text { Director }\end{array}$ & 44 & 20 & 45 & 17 & 17 & 6 \\
\hline
\end{tabular}

Figure 4.2 shows the board membership and the composition of independent directors in the board for the 5-year period of observation. The graph shows that the independent director composition in the board is consistent over the years and made up a small percentage of the total board membership. The highest board membership was recorded in 2015 and the lowest was in 2013. In term of independent director composition, there was an upwards trend for the entire 5-years period. The highest independent director composition was recorded in 2017 and the lowest was in 2013. 
INTERNATIONAL JOURNAL OF ACADEMIC RESEARCH IN BUSINESS AND SOCIAL SCIENCES Vol. 10, No. 8, 2020, E-ISSN: 2222-6990 @ 2020 HRMARS

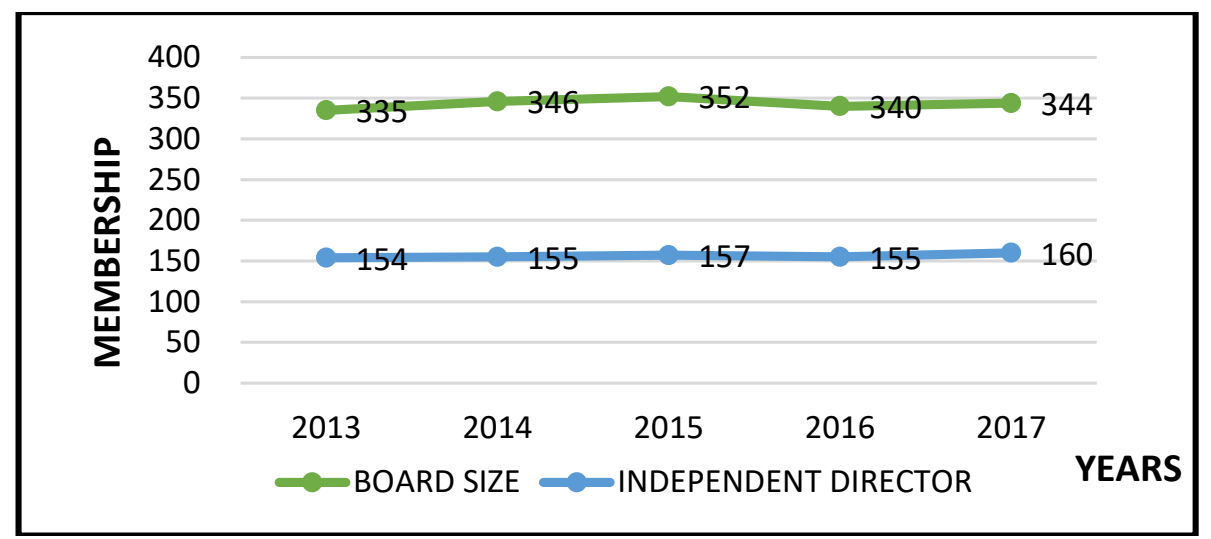

Figure 4.2: Board Membership and Independent Director Composition

\section{Board Membership and Independent Director Based on Size}

This section presents the descriptive statistics of board membership and independent director composition based on two categories being, the small category and large category. The purpose is to provide additional information pertaining to the number of directors serving in the board by grouping the board membership into large and small categories.

Table 4.4: Categorization of Board Membership

\begin{tabular}{lllllll}
\hline Category & $\mathrm{n}$ & Minimum & Maximum & Mean & Median & Std. Deviation \\
\hline $\begin{array}{l}\text { Small } \\
\text { BOD }\end{array}$ & 23 & 20 & 35 & 29 & 29 & 4 \\
$\begin{array}{l}\text { Large } \\
\text { BOD }\end{array}$ & 21 & 38 & 85 & 49 & 45 & 12 \\
\hline
\end{tabular}

Table 4.4 shows that the mean number of board membership is 29 members for the small category and 49 for the large category. About fifty per cent of the companies in the small category have 29 members while in the large category there were 45 members.

Table 4.5: Categorization of Independent Director

\begin{tabular}{|c|c|c|c|c|c|c|}
\hline Category & $\mathrm{n}$ & Minimum & Maximum & Mean & Median & Std. Deviation \\
\hline $\begin{array}{l}\text { Small Independent } \\
\text { Director }\end{array}$ & 25 & 8 & 17 & 13 & 15 & 2 \\
\hline $\begin{array}{l}\text { Large Independent } \\
\text { Director }\end{array}$ & 19 & 19 & 45 & 22 & 20 & 6 \\
\hline
\end{tabular}

Table 4.5 provides the descriptive statistics of independent director composition in which, on average, the companies' independent director composition has 13 members for the small category and 22 for the large category. About fifty per cent of the companies in the small category have 15 independent directors whereas companies in the large category have 20 independent directors. 
INTERNATIONAL JOURNAL OF ACADEMIC RESEARCH IN BUSINESS AND SOCIAL SCIENCES Vol. 10, No. 8, 2020, E-ISSN: 2222-6990 @ 2020 HRMARS

\section{Correlation Analysis}

This section presents the results of the Pearson correlation analysis that is used to examine the relationship between board size and the capital structure components.

Table 4.6: BOD Size and Return on Equity

\begin{tabular}{lcccc}
\hline BOD Category & & BOD & ROE & Debt Ratio \\
\hline Small Category & BOD & 1 & .280 & .025 \\
& & & .378 & .905 \\
& ROE & .280 & 1 & .201 \\
& & .378 & & .784 \\
Debt Ratio & .073 & .201 & 1 \\
Large Category & .730 & .784 & \\
& BOD & 1 & .200 & $.477^{*}$ \\
& ROE & .200 & .475 & .039 \\
& & .475 & .532 \\
& Debt Ratio & $.477^{*}$ & .532 & .086 \\
& & .039 & .086 & \\
*. Correlation is significant at the 0.05 level (2-tailed). & & \\
\hline
\end{tabular}

Table 4.6 shows board membership based on the small and large categories in order to see how board size impacted the firms' capital structure. The coefficient correlation between BOD size and return on equity shows that there was no significant correlation between the two variables (Small category $r=0.280$; Large category $r=0.200$ ). This means that board size has no impact on firm's equity. In term of the debt components, the result indicates that there was no significant correlation between the small board and the debt ratio $(r=0.025)$. However, large board size has a positive impact on the firm's debt ratio $(r=0.477)$. This means that board size does have an impact on the firm's debt components.

Table 4.7: Independent Director Composition and Return on Equity

\begin{tabular}{|c|c|c|c|c|}
\hline \multicolumn{2}{|c|}{ Independent Director Categories } & $\begin{array}{l}\text { Independent } \\
\text { Director }\end{array}$ & ROE & Debt Ratio \\
\hline Small & Independent Director & 1 & .247 & .073 \\
\hline Cate & & & .439 & .730 \\
\hline \multirow[t]{4}{*}{ gory } & ROE & .247 & 1 & .107 \\
\hline & & .439 & & .741 \\
\hline & Debt Ratio & .073 & .107 & 1 \\
\hline & & .730 & .741 & \\
\hline Large & Independent Director & 1 & .021 & $.517^{*}$ \\
\hline Cate & & & .941 & .023 \\
\hline \multirow[t]{4}{*}{ gory } & ROE & .021 & 1 & .472 \\
\hline & & .941 & & .076 \\
\hline & Debt Ratio & $.517^{*}$ & .472 & 1 \\
\hline & & .023 & .076 & \\
\hline \multicolumn{5}{|c|}{ *. Correlation is significant at the 0.05 level (2-tailed). } \\
\hline
\end{tabular}


INTERNATIONAL JOURNAL OF ACADEMIC RESEARCH IN BUSINESS AND SOCIAL SCIENCES Vol. 10, No. 8, 2020, E-ISSN: 2222-6990 @ 2020 HRMARS

Table 4.7 shows the correlation between independent director composition and firm's equity. The coefficient correlation shows that there was no correlation between the size of independent director serving in the board and firm's return on equity. A similar result was also observed for the large independent director composition. Therefore, it can be concluded that the size of independent director composition has no impact on the firms' equity. Although no significant correlation was found between the small size independent directors composition and debts ratio $(r=0.021)$, there was a significant correlation between large size independent director composition and the debt ratio $(r=0.517)$. Therefore, the findings suggest that the size of independent directors in the board do impact companies' debts components.

\section{Concluding Remarks}

This study examines the relationship between the size of BOD and independent directors composition and the capital structure of 44 Malaysian plantation companies listed on the main board of KLSE for a period of five years (2013 to 2017). The purpose is to understand the role of BOD as a corporate governance mechanism to control and monitor corporate managers behavior with regards to the capital structure decision. Using the data obtained from the companies' annual reports and the DataStream database, several insights were drawn from the analyses conducted in this study. Results of the Pearson correlation analysis showed that the size of BOD and independent directors composition do have an impact on firm's debts components but not on the firm's equity. This finding is consistent with Tarus (2016) who found a positive relationship between large board size and high level of firm's debt. Consistent with previous studies such as Heng et al. (2012), Alves (2015) and Ji (2016), this study also found a positive association between board size and capital structure in general. Although the study failed to establish a significant correlation between BOD size and firm's equity, there appear to be a positive direction in the relationship which supported the finding of Dagsson (2011). However, these results apply to companies operating in the Malaysian plantation industry only. Hence, it is recommended that more studies are to be carried out to examine the effect of BOD size on firms' capital structure for companies operating in other sectors or industries. Such studies are particularly important to increase understanding of the corporate governance system implemented in a particular industry and how the system help in addressing issues relating to a firm's capital structure. In addition, future study may also consider to conduct a comparative studies by taking sample companies from multiple industries. By doing so the differences in the level of corporate governance mechanism across industry can be observed. This is to determine how and whether the level of corporate governance play a role in minimizing the agency costs. Additionally, future study may also conduct a longitudinal study to examine how and whether the temporal element affect the results. By doing so, additional insights can be drawn from the findings to enhance current understanding.

\section{Theoretical and Contextual Implications}

The main objective of the current study is to examine the effect of board size and the independent director composition on firm's capital structure. The purpose is to determine whether this corporate governance mechanism is effective in monitoring and controlling the opportunistic behavior of corporate managers. Using the agency theory to underpin the study, the findings showed that board size and the presence of independent directors in the board is a useful corporate governance mechanism that can be used to mitigate the agency costs arising from the opportunistic behavior of 
INTERNATIONAL JOURNAL OF ACADEMIC RESEARCH IN BUSINESS AND SOCIAL SCIENCES Vol. 10, No. 8, 2020, E-ISSN: 2222-6990 @ 2020 HRMARS

corporate managers with respect to the capital structure decision. Theoretically, the finding supports the limitation of agency theory in explaining the fiduciary duty of corporate managers which was highlighted in Nkundabanyanga (2013). Hence, using the agency theory alone to explain the relationship between corporate governance and firm's capital structure may not be adequate. Other theories are required to provide a complete view on how this relationship can be understood. However, many of the theories which have been used in previous studies may not be applicable to a developing countries context. As most studies in this area are conducted in the developed countries context, using similar theories is not suitable since the environment scenarios in developing countries are different. Hence, selection of the theoretical lens to be used in the study has to take into consideration of these limitations.

\section{References}

Abor, J. (2007). Corporate governance and financing decisions of Ghanaian listed firms. Corporate Governance: The international journal of business in society.

Alves, P., Couto, E. B., \& Francisco, P. M. (2015). Research in International Business and Finance.

Anderson, R. C., Mansi, S. A., \& Reeb, D. M. (2004). Board characteristics, accounting report integrity, and the cost of debt. Journal of accounting and economics, 37(3), 315-342.

Berger, P. G., Ofek, E., \& Yermack, D. L. (1997). Managerial entrenchment and capital structure decisions. The journal of finance, 52(4), 1411-1438.

Black, B., \& Kim, W. (2012). The effect of board structure on firm value: A multiple identification strategies approach using Korean data. Journal of financial economics, 104(1), 203-226.

Boučková, M. (2015). Management accounting and agency theory. Procedia Economics and Finance, 25, 5-13.

Butt, S. A., \& Hasan, A. (2009). Impact of ownership structure and corporate governance on capital structure of Pakistani listed companies. International Journal of Business \& Management, 4(2).

Daily, C. M., \& Dalton, D. R. (1993). Board of directors leadership and structure: Control and performance implications. Entrepreneurship theory and practice, 17(3), 65-81.

Dagsson, S., \& Larsson, E. (2011). How age diversity on the Board of Directors affects Firm Performance.

Germain, L., Galy, N., \& Lee, W. (2014). Corporate governance reform in Malaysia: Board size, independence and monitoring. Journal of Economics and Business, 75, 126-162.

Heng, T. B., Azrbaijani, S., \& San, O. T. (2012). Board of directors and capital structure: Evidence from leading Malaysian companies. Asian Social Science, 8(3), 123-136.

Jensen, M. C. (1986). Agency costs of free cash flow, corporate finance, and takeovers. The American economic review, 76(2), 323-329.

Jermias, J., \& Gani, L. (2014). The impact of board capital and board characteristics on firm performance. The British Accounting Review, 46(2), 135-153.

Ji, A. E. (2016). The impact of board size on firm-level capital Investment efficiency. International Journal of Economics and Finance, 8(10), 110-120.

Kumar, N., \& Singh, J. P. (2013). Effect of board size and promoter ownership on firm value: Some empirical findings from India. Corporate Governance (Bingley), 13(1), 88-98.

Nkundabanyanga, S. K., Ahiauzu, A., Sejjaaka, S. K., \& Ntayi, J. M. (2013). A model for effective board governance in Uganda's services sector firms. Journal of Accounting in Emerging Economies.

Raheja, C. G. (2005). Determinants of board size and composition: A theory of corporate 
INTERNATIONAL JOURNAL OF ACADEMIC RESEARCH IN BUSINESS AND SOCIAL SCIENCES

Vol. 10, No. 8, 2020, E-ISSN: 2222-6990 @ 2020 HRMARS

boards. Journal of financial and quantitative analysis, 283-306.

Ranti, U. O. (2013). The effects of board size and CEO duality on firms' capital structure: A study of selected listed firms in Nigeria. Asian Economic and Financial Review, 3(8), 1033.

Shapiro, A. C., \& Balbirer, S. D. (2000). Modern corporate finance: a multidisciplinary approach to value creation (No. s 2, pp. 2-5). Upper Saddle River, NJ: Prentice Hall.

Tarus, D. K., \& Ayabei, E. (2016). Board composition and capital structure: evidence from Kenya. Management Research Review.

Ting, P. H. (2011). The determinants of board size and composition: Evidence from Taiwan banks. African Journal of Business Management, 5(17), 7622-7631. 